http://doi.org/10.35784/iapgos.1929

\title{
MANAGEMENT OF POWER IN ASPECTS OF ENERGY PRODUCTION PRICES FOR FUEL ENERGY GENERATORS
}

\author{
Konrad Zuchora \\ Lublin University of Technology, Faculty of Electrical Engineering and Computer Science, Lublin, Poland
}

Abstract. The article describes the impact of a fuel-consuming power generator on energy production costs. The research is based on a thermodynamic engine model for which the energy source is hydrocarbon fuel. The results of the studies on the thermodynamic engine are energy cost functions for which the variable is electrical power. The presented characteristics reflect the impact of fuel prices on the minima of the cost function. In addition, the characteristics reflect the location of the extremes of functions in the coordinate system relative to the maximum of the function of efficiency. The article concludes with a cost model for thermodynamic engines for which hydrocarbon fuel is purchased. Article proposes the cooperation of generators with renewable sources to increase and stabilize the power rating of power systems.

Keywords: energy production costs, distributed power generation, renewable energy sources

\section{ZARZĄDZANIE MOCA W ASPEKTACH CEN WYTWARZANIA ENERGII DLA GENERATORÓW ZUŻYWAJĄCYCH PALIWO}

\begin{abstract}
Streszczenie. Artykut opisuje wptyw mocy generatora energii zużywajacego paliwo na koszty wytwarzania energii. Badania bazuja na modelu silnika termodynamicznego, dla którego źródtem energii jest paliwo węglowodorowe. Efektami badań silnika termodynamicznego sa funkcje kosztów energii, dla których argumentem jest moc elektryczna. Zaprezentowane charakterystyki uwzgledniaja wplyw cen paliwa na minima funkcji kosztów. Ponadto charakterystyki odzwierciedlaja położenie ekstremów funkcji w układzie wspótrzędnych względem maksimum funkcji sprawności. W podsumowaniu artykut prezentuje model wyznaczania kosztów dla silników termodynamicznych, dla których kupowane jest paliwo węglowodorowe. W artykule zaproponowano wspótprace generatorów ze źródłami odnawialnymi w celu zwiększenia i stabilizacji mocy znamionowych systemów elektroenergetycznych.
\end{abstract}

Słowa kluczowe: koszty wytwarzania energii, generacja rozproszona, odnawialne źródła energii

\section{Introduction}

In Europe, the future intention of the national power systems is to achieve participation of distributed energy based on renewable sources $[3,4]$. Due to the use of renewable energy in power systems and improvement of energy efficiency in social and industrial areas, the pro-ecological ideas of reducing carbon dioxide and energy costs are being promoted as future areas of European energy infrastructure.

Current European Union countries and global economies attach importance to reducing energy consumption in industry and households, while environmental pollution and climate change are at the center of attention of the whole world [11]. In Europe, due to the consistent pursuit of the goal of reducing carbon dioxide production, there is currently a need and the will to use energy produced from renewable sources, to improve energy efficiency in energy generation and to reduce energy consumption indicators.

With the high social costs of using fossil fuels, deteriorating climate changes and local environmental problems, renewable energy and combined production techniques are considered to be effective methods of clean energy generation, the use of which enjoys interest in distributed generation and micro power systems .

In Poland, thanks to the establishment of a new energy law [15], which applies to "energy prosumers" and small energy production, new possibilities are arising and more attention is currently being paid to the multi-criteria aspects of distributed energy generation and power systems design $[2,8]$. These multicriteria aspects include renewable energy sources for generating electricity and heat in power systems. At present, the advantages and disadvantages as well as the technical and economic possibilities of various energy production techniques are being considered in home power systems when the installation of the heating and hot water supply are designed [14].

The expected result of work optimization in the power system is to achieve energy system self-sufficiency. By increasing the energy produced from renewable sources and improving the energy efficiency in the power systems and devices used in homes and industry, international power systems and home systems are seeking to achieve reduced fossil fuel usage.

Issues of lifestyles indulging in excessive energy consumption are currently being raised around the world. [6]. Along with the increase in social consumption, particularly strong increases in energy consumption are being observed in the power industry.
Around the world, rapid increases in energy consumption are being observed in developing and also developed countries. With the rapid development of national economies, side effects resulting from the production of energy from fossil fuels are suddenly becoming growing problems.

Currently, the main goal of The European Union's European global energy policy is the introduction an energy action program to reduce fossil fuel usage. Therefore, the creation of new, wellthought-out, flexible, stable and efficient systems for the production of power and heat is an important project regarding the functioning of national power systems. The trend of rising energy prices and the future possibility of a global crisis makes energy resource management criteria crucial from an economic perspective.

Over the past several years, experience in use of renewable sources has resulted in confidence in the safety of energy production from renewable sources and the use of clean energy is becoming more common [5]. In connection with the general upward trend in energy prices, and to meet the growing demand for energy, the opportunities to use energy resources accumulated in renewable energy and the techniques of clean, efficient energy production are attracting more attention in small and medium power systems around the world.

In power systems, the details and goals which connect the functioning of power industry can in time perspective easily modified in the unintended direction, and in such cases the effects of these modifications in the organization stages are new for users and sometime are also confusing. Therefore at the design stage, planning the results of future events in the structure of the power system need special attention [10].

\section{Characteristics of distributed generation}

Small generators for power production using combined power generation techniques have developed rapidly in recent years and are considered to be appropriate for distributed generation [1].

Distributed generation systems are suitable for satisfying mainly local needs and are used for the production of so-called green energy.

In distributed generation, the aspect of maximizing profits and improving the rate of use of renewable energy are important nowadays. In small thermodynamic engines, saving one joule of consumed energy results on average in two to four joules of saved energy from fuel. 
The economic advantages of hybrid and combined energy production systems and the use of distributed generation techniques, together with renewable energy sources, are the most promising future prospects of distributed power generation systems [12]. The ease of configuring the characteristics of distributed energy generation together with the capabilities of working with combined power systems, make the design of renewable energy with combined energy production systems universal and predisposed to achieve the highest efficiency.

Most distributed generation systems, thanks to the possibility of using renewable energy, focus on opportunities that provide reductions in carbon dioxide emissions and optimization of fuel consumption.

In distributed generation systems, due to the functionality of the low-power generation technique, it is currently preferable use dedicated combustion aggregates and micro engines intended to work in cogeneration [7,9] or thermodynamic combined cycles. The architecture and dimensions of the distributed generation systems can be configured towards achieving economic system goals by a combination of power dimensions of rated electricity and heat in system operation.

Optimal work management and architectural systems power dimensioning is an important issue in power systems using combined power generation. Too-small power dimensions of the distributed generation system can cause reliability problems. Toolarge power dimensions can generate unnecessary costs from the fuel energy losses. The optimal configuration of energy sources can reduce costs and also improve the overall reliability and efficiency of the system.

In the distributed generation technique, the power grid can be considered as an energy storage system. The work model that uses the power grid as infinite storage is called "net metering" [13]. In the system distributed generation technique, the possibility to work with connection to the grid is in most cases reliable. Connecting the system to the grid enables energy to be imported from the grid and charged to the system loads. Distributed generation systems can work autonomously or with power grids. When personal generators in the system are not able to power the personal loads, the required extra energy can be taken from the grid. When the system generators produce more power than the system's loads can consume, the excess energy can be sold to the grid or can be stored in the system's energy store.

The use of distributed generation systems energy sources is becoming standard in many applications. In distributed generation systems, failure of one generator does not shut down the entire system because the other working generators in the system are able to supply energy constantly.

The use of the power level at which energy costs of the fuelbased energy generator in the system of distributed generation are minimal also has disadvantages. Low power generators achieve low energy density per unit mass and low efficiency, which is a generating problem of suboptimal use of the energy stored in the fuel, which in effect results in the problem of increased carbon dioxide emissions. As a result of these disadvantages, there are currently doubts regarding the operation of the entire power system and the design of power system dimensions which are using renewable sources as power support.

The solution here is to use the combined systems, simultaneously producing different types of energy, mainly heat and electricity.

\section{Equations model}

The following functions represent the characteristics of a thermodynamic engine powered by hydrocarbon fuel, which is mechanically coupled which an electrical generator. The power generated in the model is electricity.

The cost equations and the price family characteristics presented in article are based on a model engine. The function $\eta_{e g}\left(P_{e g}\right)$ presented on Figure 1 represents the electrical efficiency of an engine powered by natural gas. The model $P_{f}\left(P_{e g}\right)$ fuel power function (Fig. 2) includes the internal energy losses in the engine and represents the energy supplied to the engine together with the fuel.

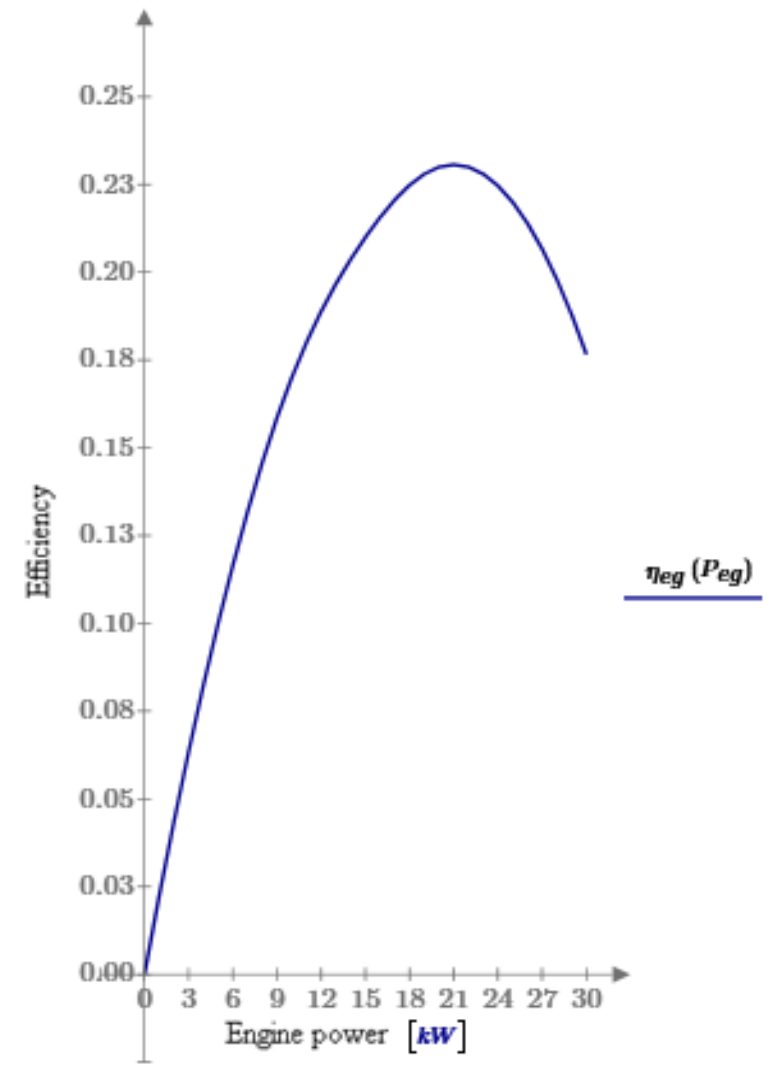

Fig. 1. Partial efficiency characteristics of fossil fuel engine

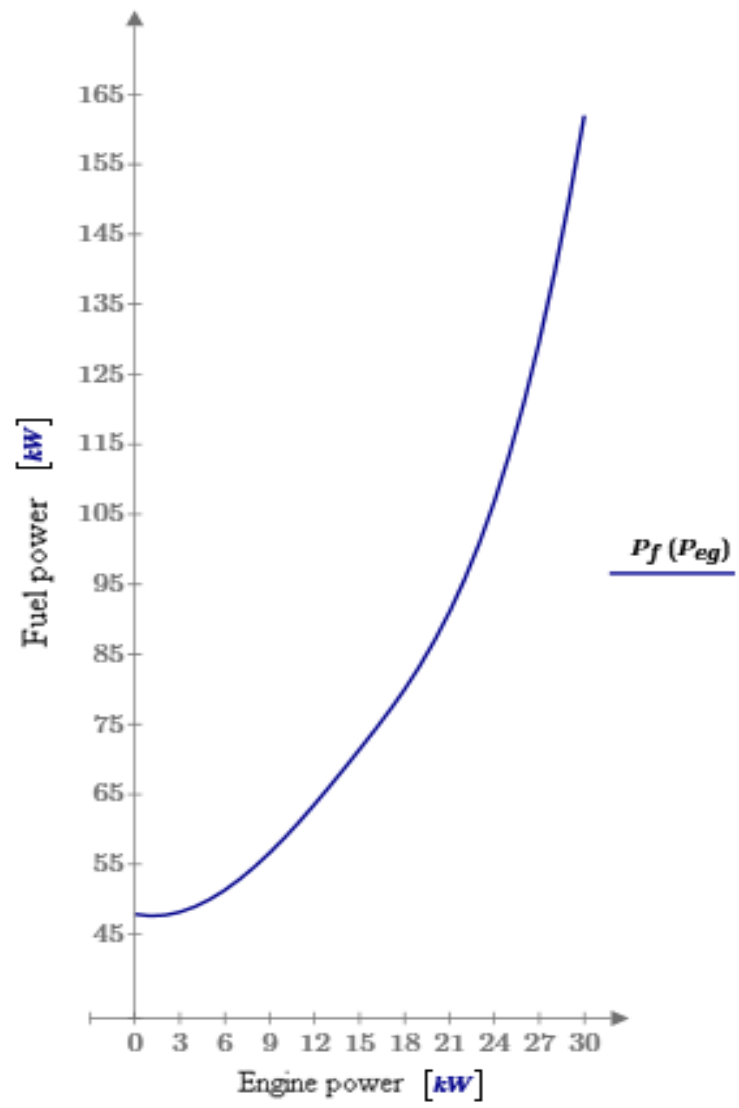

Fig. 2. Function of the power supplied to the model engine with the fuel 
By dividing time unite the energy contained in the fuel for $P_{f}\left(P_{e g}\right)$ function is simplified to the fuel power. The variable of the $P_{f}\left(P_{e g}\right)$ function is electrical power.

The fuel prices in the equations have been set in the range from $0.9 \mathrm{zt} / \mathrm{kWh}$ to $0.1 \mathrm{zt} / \mathrm{kWh}$. The curves Figure 3 have been drawn up for a fossil fuel calorific value of $34 \mathrm{MJ} / \mathrm{m}^{3}$ and for four equal intervals between fuel prices.

The reference price function $C_{e 4}\left(P_{e g}\right)$ is constant for the entire engine power range and assumes a value corresponding only to the fuel price in Figure 3.

After including the efficiency function, the prices of the produced energy increase and the functions of the energy prices become non-linear and reach minimums. The same relationship described above applies to the energy cost function.

The functions from $C_{e 0}\left(P_{e g}\right)$ to $C_{e 3}\left(P_{e g}\right)$ shown in Figure 3 represent the prices of electrical energy generated in the engine model for different fuel prices.

$$
\mathrm{C}_{\mathrm{e} 0}\left(\mathrm{P}_{\mathrm{eg}}\right)=\frac{\mathrm{F}_{\mathrm{p} 0} \cdot\left(2-\eta_{\mathrm{e}}\left(\mathrm{P}_{\mathrm{eg}}\right)-\eta_{\mathrm{e}}\left(\mathrm{P}_{\mathrm{eg}}\right)^{2}\right)}{1+\eta_{\mathrm{e}}\left(\mathrm{P}_{\mathrm{eg}}\right)^{2}}
$$

where $F_{p}$ is the fuel price, $P_{e g}$ is the electric power, and $\eta_{e}$ is the electrical efficiency.

The reference cost of generating electrical energy in the model engine is represented by the following function (2). The reference function includes only the fuel price and engine fuel consumption function whose variable is electric output power.

$$
E_{c p 4}\left(P_{e g}\right)=F_{p 3} \cdot P_{f}\left(P_{e g}\right) \cdot h_{r}
$$

where $h_{r}$ equals 3600 seconds, and $P_{f}\left(P_{e g}\right)$ is the fuel power.

The energy production costs represent the functions found in Fig. 4. The model of costs of generating electrical energy, which include the electrical efficiency and energy losses, are represented by equations (3) and (4).

$$
\begin{aligned}
& E_{c p 0}\left(P_{e g}\right)=\frac{F_{p 0} \cdot P_{f}\left(P_{e g}\right) \cdot\left(2-\eta_{e}\left(P_{e g}\right)-\eta_{e}\left(P_{e g}\right)^{2}\right)}{1+\eta_{e}\left(P_{e g}\right)^{2}} \cdot h_{r} \\
& E_{c p 3}\left(P_{e g}\right)=\frac{F_{p 4} \cdot P_{f}\left(P_{e g}\right) \cdot\left(2-\eta_{e}\left(P_{e g}\right)-\eta_{e}\left(P_{e g}\right)^{2}\right)}{1+\eta_{e}\left(P_{e g}\right)^{2}} \cdot h_{r}
\end{aligned}
$$

\section{Findings}

The electrical costs based on the model of the thermal engine consuming energy contained in fuel and the energy production price model are illustrated in Figure 4.

Figure 3 gives the family of price characteristics of electrical energy generated in the engine for various fuel prices. Figure 3 also gives the model generator power regulation range. The power regulation is dependent on the fuel prices.

Figure 3 and Figure 4 show that the cost and price characteristics of the energy produced have minimums at different power levels and the minima positions are independent of each other. The analysis shows that the dislocations of costs and the energy price minima are caused by the non-linearity of the characteristics of the power supplied to the engine together with the fuel (Fig. 2). The more electrical power the generator produces, the more fuel it consumes but the increased proportions of fuel supplied with increasing power are disproportionate, and they have an upward trend. The minima of the operating costs of a fuel-consuming engine are found at $13.28 \mathrm{~kW}$ for a generator that can reach $30 \mathrm{~kW}$. And the minimum energy prices are at $22 \mathrm{~kW}$. For different energy prices, the cost and energy price functions reach minimums at the same power. In addition, the efficiency function reaches maximum when the electric power reaches $21 \mathrm{~kW}$ (Fig. 1).

The effect on the price of the generated energy from an engine working with low power is evident in Fig. 3. The $C_{e O}\left(P_{e g}\right)$ function for low power is more non-linear than the $C_{e 4}\left(P_{e g}\right)$ function.

In Figure 4, the unit of electricity costs is the Polish monetary unit. For an electrical power output of $22 \mathrm{~kW}$ and a fuel price of
0.3 Polish zlotys per kilowatt, the cost of the electricity generated in the machine reaches the value of 30 zlotys.

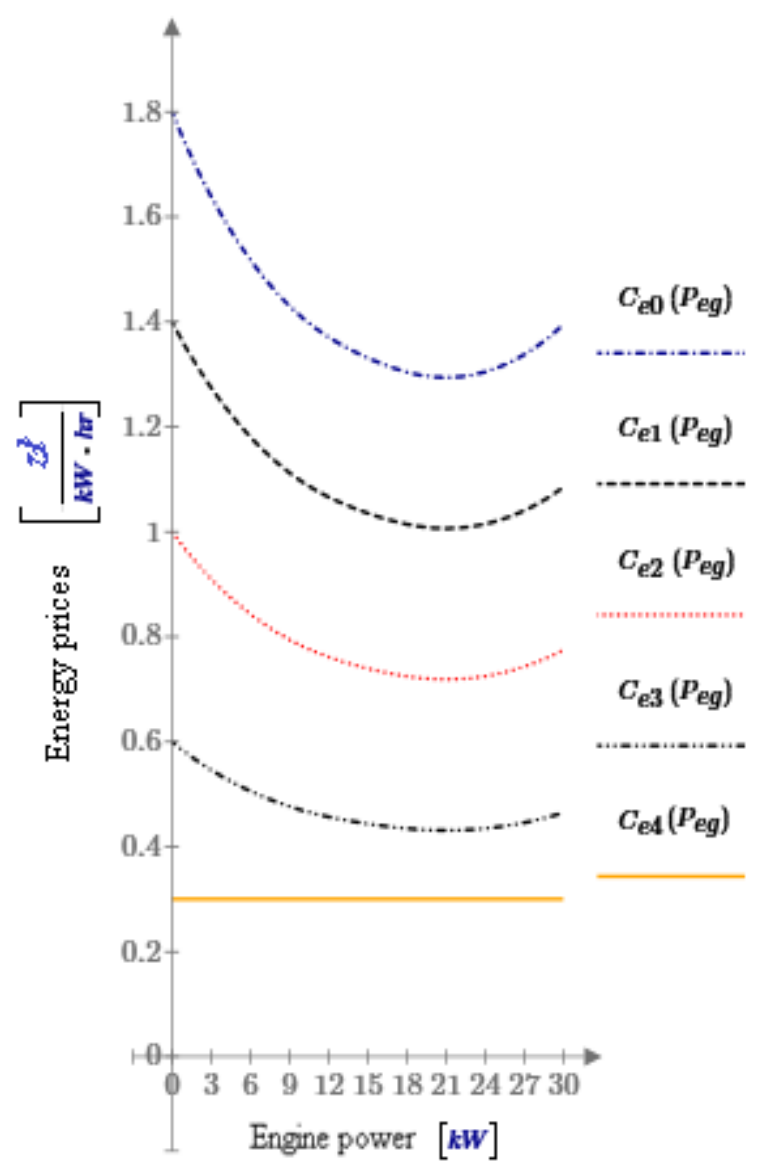

Fig. 3. Functions of electrical production prices

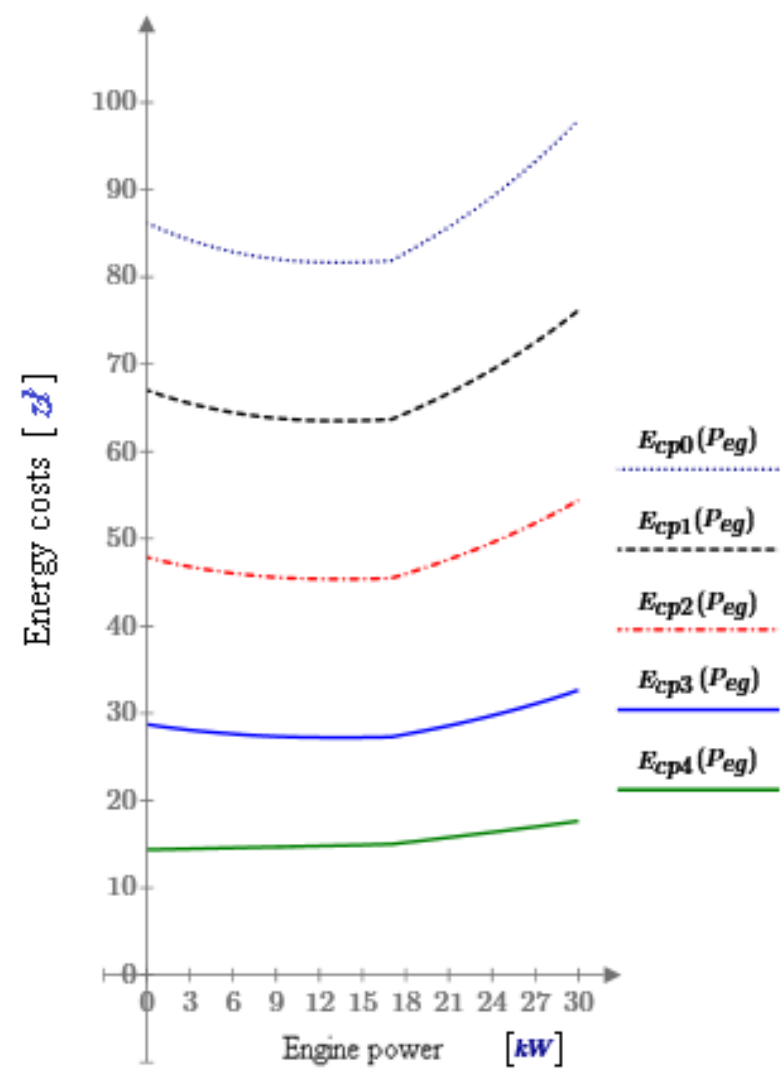

Fig. 4. Electrical cost resulting from the fuel consumption and model efficiency of the engine. 
Figure 4 shows that the functions of heat costs from $E_{c p 0}\left(P_{e g}\right)$ to $E_{c p 3}\left(P_{e g}\right)$ have a minimum. An exception is the $E_{c p 4}\left(P_{e g}\right)$ function, which does not consider energy losses resulting from the generator efficiency.

\section{Summary}

In the studies, the impact of energy prices on a fuel-powered engine's economic power range is included in the results. Figure 2 maps the ratio between the fuel price and the price of the produced energy and maps the influence of the sale price on a cost efficient power control range of the model generator.

The studies give the energy price characteristics of the model generator. Designated families of energy price characteristics include the electrical efficiency of the model.

For the owner of an energy generator, the functions in Figure 3 result from the economic profitability of including the costs of purchasing fuel and energy losses which result from the efficiency of the engine in the price of the produced energy.

In the performed analysis, it was shown that the technical minima of generator operation, related to power are dependent on the prices of the fuel supplying the generator, economic profits and the sale price of the generated energy in the engine.

Assuming that renewable energy sources produce energy cheaper than a model engine and can produce energy for the load in the operating conditions of the system for which the work of the engine is unprofitable. The use of energy storage charged with energy from renewable energy sources is the solution to problem of power regulation limited by energy prices in the power systems.

To minimize the operating costs of the engines from fuel, an optimal power management strategy at an acceptable cost level is crucial.

In contrast to energy produced from fossil fuels, energy produced from renewable sources in distributed generation, mainly wind energy, has an uncertain generation cycle. The weather-limited uncertainty of renewable energy sources means that power systems with optimal power operation for the minimum cost criterion cannot fully exploit the possibilities that arise from the rated power of the generators.

Currently, one of the main challenges for systems of distributed generation is the design of multi-objective power management strategies which ensure that the power meets the demand from its own loads, despite the intermittent nature of renewable energy, along with the reduction of work costs and achieving the intended goals.

\section{References}

[1] Beith R.: Small and micro combined heat and power (CHP) systems: advanced design, performance, materials and applications, Elsevier 2011.

[2] Burke M. J., Stephens J. C.: Political power and renewable energy futures: A critical review. Energy Research \& Social Science 35/2018, 78-93, https://doi.org/10.1016/j.erss.2017.10.018.
[3] Connolly D., Lund H., Mathiesen B. V.: Smart Energy Europe: The technical and economic impact of one potential $100 \%$ renewable energy scenario for the European Union. Renewable and Sustainable Energy Reviews 60/2016, 16341653, https://doi.org/10.1016/j.rser.2016.02.025.

[4] Hammons T. J.: Integrating renewable energy sources into European grids. International Journal of Electrical Power \& Energy Systems 30(8)/2008, 462475, https://doi.org/10.1016/j.ijepes.2008.04.010.

[5] Klein S., Coffey S.: Building a sustainable energy future, one community at a time. Renewable and Sustainable Energy Reviews 60/2016, 867-880, https://doi.org/10.1016/j.rser.2016.01.129.

[6] Kwac J., June F., Ram R.: Lifestyle segmentation based on energy consumption data. IEEE Transactions on Smart Grid 9(4)/2016, 2409-2418, https://doi.org/10.1109/TSG.2016.2611600.

[7] Marnay C., Venkataramanan G., Stadler M., Siddiqui A.S., Firestone R., Chandran B.: Optimal Technology Selection and Operation of CommercialBuilding Microgrids. IEEE Transactions on Power Systems 23(3)2008, 975982, https://doi.org/10.1109/TPWRS.2008.922654.

[8] Mengelkamp E., et al.: Designing microgrid energy markets: A case study: The Brooklyn Microgrid. Applied Energy 210/2018, 870-880, https://doi.org/10.1016/j.apenergy.2017.06.054

[9] Pfeiffer R., Verstege J.: Committing and dispatching power units and storage devices in cogeneration systems with renewable energy sources. 1996, 21-25, https://doi.org/10.1049/cp:19960230.

[10] Ramakumar R., Chiradeja P.: Distributed generation and renewable energy systems. IECEC'02. 2002 37th Intersociety Energy Conversion Engineering Conference, 2002., 716-724, https://doi.org/10.1109/IECEC.2002.1392136.

[11] Sicard P., et al.: Global topics and novel approaches in the study of air pollution, climate change and forest ecosystems. Environmental pollution 213/2016, 977 987, https://doi.org/10.1016/j.envpol.2016.01.075.

[12] Wang J, et al.: Energy, exergy, exergoeconomic and environmental (4E) analysis of a distributed generation solar-assisted CHP (cooling, heating and power) gas turbine system. Energy 175/2019, 1246-1258, https://doi.org/10.1016/j.energy.2019.03.147.

[13] Yamamoto Y.: Pricing electricity from residential photovoltaic systems: A comparison of feed-in tariffs, net metering, and net purchase and sale. Solar Energy 86(9)/2012, 2678-2685, https://doi.org/10.1016/j.solener.2012.06.001.

[14] Zuchora K.: Renewable energy sources and cogeneration costs in aspects of distributed generation. The Scientific Papers of Faculty of Electrical and Control Engineering Gdańsk University of Technology 53/2017, 151-154.

[15] Act, R. E. S. "Renewable Energy Act of 07 June 2018 r." Dz. U 2015 (2015). http://prawo.sejm.gov.pl/isap.nsf/DocDetails.xsp?id=WDU20180001276

\section{Ph.D. Student Konrad Zuchora \\ e-mail: zuchorakonrad@gmail.com}

The researcher is interested in team work of fossil fuels and renewable energy sources in power systems. The research objects are hybrid and combined power generation systems. The main interest is the multicriteria schedules of combined power generation systems and their optimization cycles. In addition, the researcher is interested in the dimensions of power systems that also use energy storage. The researcher has experience in the criteria design of power microsystems and thermodynamic engines and also the geometry of turbine blades.

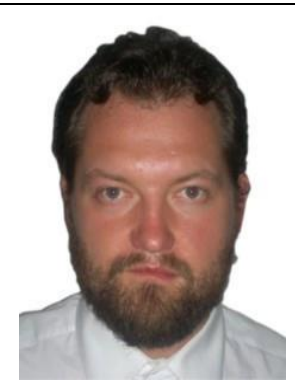

http://orcid.org/0000-0002-9067-9875

otrzymano/received:21.05.2020

przyjęto do druku/accepted: 15.09 .2020 